
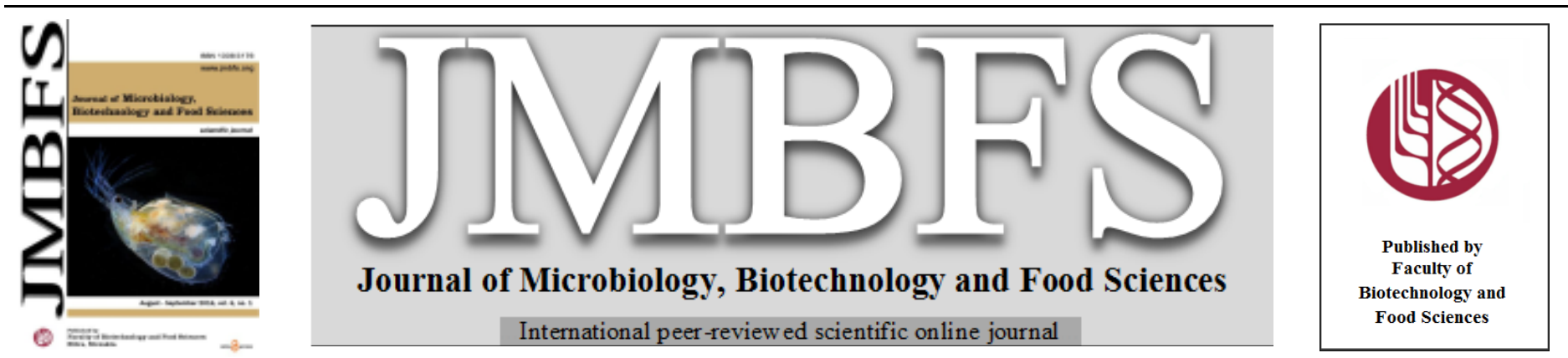

\title{
QUALITY EVALUATION OF ZOBO (HIBISCUS SABDARIFFA) JUICE PRESERVED WITH MORINGA (MORINGA OLEIFERA) OR GINGER (ZINGIBER OFFICINALE) EXTRACTS AT DIFFERENT STORAGE CONDITIONS
}

\author{
Olasunmbo Abolanle Ajayi ${ }^{* 1}$, Arome Grace Lessor ${ }^{1}$, Oluwabunmi Oluwafunmilayo Akinwunmi ${ }^{1}$
}

Address(es):

Bowen University, Faculty of Agriculture, Department of Food Science and Technology, P.M.B. 284, Iwo, Nigeria

*Corresponding author: sunmbo.ajayi@gmail.com

doi: $10.15414 / j m b f s .2016 .6 .1 .730-736$

\section{ARTICLE INFO}

Received 12.9. 2015

Revised 15. 4. 2016

Accepted 19. 4. 2016

Published 1. 8. 2016

Regular article open $\partial_{\text {ACCESS }}$

\begin{abstract}
This study aimed to improve the storability of zobo juice naturally. Zobo juice infused with extracts of Moringa seeds or ginger at $(0.5$ and $1 \%$ ), control ( $0 \%$ preservative) and, food vendor prepared (FVPZ) zobo were evaluated for 8 weeks. Samples were stored at ambient or refrigeration temperatures and physico-chemical, microbial load and sensory qualities of the juice were analyzed using standard methods. There were drops in $\mathrm{pH}$ values after pasteurization from (2.44- 2.75) to (2.31 - 2.58). Vitamin $\mathrm{C}$ increased with storage in preserved juice but reduced in control and FVPZ. There were significant $(\mathrm{p}<0.05)$ differences between samples in total titratable acidity. All of the samples had varying levels of microbial load. Microbial load of raw material ranged from $\left(7.8 \times 10^{4}\right.$ to TNTC), $\left(3.0 \times 10^{3}\right.$ to $\left.3.0 \times 10^{4}\right)$ and $\left(5.6 \times 10^{4}\right.$ to $\left.8.0 \times 10^{4}\right) \mathrm{CFU} / \mathrm{g}$, while zobo juice on day 0 had counts ranging from $\left(2.23 \times 10^{3}\right.$ to TNTC); $\left(3.0 \times 10^{2}\right.$ to $\left.8.0 \times 10^{4}\right) ;\left(4.0 \times 10^{4}\right.$ to $\left.5.6 \times 10^{4}\right)$, CFU/mL for total viable, staphylococcal and fungal count respectively. There was zero enterobacteriaceae count on day 0 but increased during storage. Moringa and ginger zobo juice overall had reduced microbial load during storage compared to zobo without preservative. On day 0 show that FVPZ was more liked: appearance (4.5), aroma (4.5), taste (4.4) and general acceptability (4.7) but scores degenerated during storage. At 8 weeks of storage, $0.5 \% \mathrm{GZ}$ scored higher in all attributes. Refrigeration retarded microbial growth but did not influence sensory scores. Study concludes that incorporation of moringa or ginger extracts into zobo was effective in improving storability of juice but ginger preserved juice was preferred.
\end{abstract}

Keywords: Zobo juice, Roselle, ginger, Moringa seeds, drum stick, preservative

\section{INTRODUCTION}

Locally produced non-alcoholic drinks such as Kunun zaki and zobo are popular in Northern Nigeria (Osuntogun, 2004) and are gaining popularity in other parts of Nigeria because of the low price. Zobo is prepared from the dried calyces of the Roselle (Hibiscus sabdariffa) plant. Roselle is popularly acclaimed worldwide for its health claims (Adegunloye et al., 1996; McKay et al., 2008), uses in foods such as herbal teas (Akanya et al., 1997), jams (Clydescale $\boldsymbol{e t}$ al., 1979), colourant (Wrolstad, 2000) and more. Although, zobo is a popular and cheap beverage, one of the major drawbacks is the quality of the raw materials (Roselle calyces, water and bottles) used in preparation and packaging of the juice. Furthermore, it has been documented that the drink deteriorates rapidly within 1-2 days (Samy, 1980; Omemu et al., 2006) if not refrigerated. This deterioration is most likely due to the activity of microorganisms (Omemu et al., 2006), making the drink microbiologically unfit, therefore unsafe for consumption.

Concerned consumers want foods and beverages that are wholesome and microbiologically safe. Preservation involves controlling the growth and metabolic activities of spoilage microorganisms in foods, in order to extend shelf life of preserved foods (Jay et al., 2000). Preservatives can be either chemical such as sodium benzoate or naturally occurring plant compound such as antioxidants. But the inclusion of chemical preservatives in foods is problematic because of toxicity effect on consumers (Bedin et al., 1999; Adesokan et al., 2013). Plant substances with aromatic, strong taste and antimicrobial properties are commonly used to enhance the taste of foods and inadvertently reduce microbial load (Lanciotti et al., 2004). Moringa olifera plant has been documented to have food and medicinal capabilities (Lipipun et al., 2003; Ashok and Pari, 2003; Tahiliani and Kar, 2000), and also antifungal activities (Nwosu and Okafor, 1995). Furthermore, chloroform extracted M. olifera seeds has been shown to have antifungal and anti-mould activity (Caceres and Lopez, 1991; Bukar et al., 2011). Spices such as cinnamon and ginger are also commonly employed in foods for their antimicrobial and preservative effect (Bello and Adeleke, 2012). Although a lot of work has been done on preservation of zobo with various spices (i.e. alligator pepper, ginger and garlic) and chemicals (Nwachukwu et al., 2007; Ogiehor et al., 2008; Nwokocha et al., 2012; Braide et al., 2012), there is no information on the effect of Moringa olifera seed extract on the shelf-life of zobo juice. Sensory evaluation is a scientific method that measures possible consumer perception of the product using the senses of sound, sight, smell, touch and taste (Stone and Sidel, 2004). Because of increased interest and potential in commercializing zobo juice, sensory analysis is also important in order to determine general acceptability or likeness of the product. Therefore, the objectives of this study were to improve the storability of zobo juice and investigate the effect of natural preservatives (moringa or ginger) extracts on the physico-chemical, microbiological load and general acceptability of the resulting zobo juice during storage.

\section{MATERIALS AND METHODS}

Dry calyces of $H$. sabdariffa, $M$. oleifera seeds and fresh ginger rhizomes were obtained from local Odo-Ori market in Iwo, Osun State, Nigeria. Dried Roselle calyces were manually cleaned to remove stones and other unwanted debris, washed thoroughly in sterile de-ionized water and dried in the cabinet dryer (Model F300, Chris Alex Engineering, Ibadan, Nigeria) at $\left(50{ }^{\circ} \mathrm{C}\right)$ for 8 hours.

Preparation of Moringa oleifera seeds and ginger (Zingiber officinale) powder

Approximately $100 \mathrm{~g}$ of dried pods containing the seeds of Moringa oleifera were further dried at room temperature until the pods exposed the seeds. Also, about $100 \mathrm{~g}$ of fresh ginger rhizome was cleaned, chopped into small pieces and dried in a laboratory oven (Gen Lab, Widens, England) at $50{ }^{\circ} \mathrm{C}$ for 8 hours prior to the commencement of the study. After drying, both moringa seeds and ginger were ground (MasterChef blender MC-BL1544, China) into powder and stored in a clean air tight container in the Food Science Laboratory at room temperature $\left(32 \pm 2{ }^{\circ} \mathrm{C}\right)$ until used. 


\section{Preparation of zobo juice}

Zobo juice was prepared according to Adesokan et al., (2013) with slight modification. Briefly, $300 \mathrm{~g}$ of cleaned calyces of $H$. sabdariffa was added to $1 \mathrm{~L}$ of hot boiling water, left to stand for $20 \mathrm{~min}$ and then filtered with white muslin cloth. The resulting zobo juice was separately blended with $(0.5 \%$ and $1 \% \mathrm{w} / \mathrm{v})$ of moringa or ginger powder. Then, $15 \mathrm{~g}$ of sugar/L was added to each blend of zobo juice and the juice without any preservative served as control. About $250 \mathrm{~m}$ of the filtrate was hot filled into sterile plastic bottles, and further pasteurized at $75{ }^{0} \mathrm{C}$ for $20 \mathrm{~min}$. Overall; there were six sets of samples divided into 4 main groups thus:

a. Zobo juice without treatment (Control)

b. Zobo juice + Ginger $(0.5 \%$ and $1 \%$, w/v) inclusion

c. Zobo juice + Moringa $(0.5 \%$ and $1 \%, \mathrm{w} / \mathrm{v})$ inclusion

d. Food vendor prepared zobo

Food vendor prepared zobo juice was purchased same day this study's juice was prepared for comparison. Each sample set was further divided in two groups. One group was kept on the Laboratory shelf at room temperature $\left(32 \pm 2{ }^{0} \mathrm{C}\right)$, while the other was kept in the refrigerator $\left(10 \pm 2{ }^{\circ} \mathrm{C}\right)$.

\section{PHYSICO-CHEMICAL ANALYSES OF ZOBO JUICE}

\section{Determination of $\mathbf{p H}$}

About $10 \mathrm{~mL}$ of each sample was dispensed into sterile beaker, diluted with 10 $\mathrm{mL}$ of distilled water and mixed thoroughly. Samples were allowed to equilibrate and $\mathrm{pH}$ reading in triplicates were recorded (Mettler Toledo AG 8603, Switzerland). Values were taken at day 0 and during storage (2, 4, 6 and 8) weeks.

\section{Total Titratable Acidity}

The total titratable acidity (TTA) (expressed as lactic acid) was determined on day 0, using Official method of analysis (AOAC, 1990). Briefly,

$1 \mathrm{~g}$ of sample was diluted in $10 \mathrm{~mL}$ of distilled water and titrated against $(0.025 \mathrm{~N})$ sodium hydroxide with phenolphthalein as an indicator. TTA was calculated as lactic acid and expressed as percentage.

\section{Vitamin C determination}

Ascorbic acid contained in the zobo juices was determined by titrimetric method using iodine according to AOAC, (1990). About $20 \mathrm{~mL}$ aliquot of the zobo juice was pipetted into a flask and $150 \mathrm{~mL}$ of distilled water plus $1 \mathrm{~mL}$ of $(0.5 \%)$ starch indicator solution was added. The samples were titrated with $0.005 \mathrm{~mol} \mathrm{~L}^{-1}$ iodine solution. The concentration of ascorbic acid in each sample was expressed as $\mathrm{mg}$ ascorbic acid/100 $\mathrm{ml}$ of sample.

\section{Microbiological analysis}

Microbial analysis was carried out on the raw materials (Ginger (Zingiber officinale), Moringa oleifera, Hibiscus sabdariffa and sugar) used in producing zobo juice. Microbial count was carried out using plate count agar (PCA) for total viable (TVC), Mannitol salt agar (MSA) for staphylococci count and Potato dextrose agar (PDA) for fungal count (Park scientific London, UK). One gram of each raw material was weighed separately into $9 \mathrm{~mL}$ of peptone water and furthe dilution up to $10^{-3}$ was made as described by Ogbuile et al. (1998). Using the pour plate method, $1 \mathrm{~mL}$ of $10^{-3}$ dilution was aseptically transferred into the petri dishes in duplicates for each agar, incubated at $37{ }^{\circ} \mathrm{C}$ overnight and enumerated while PDA was incubated for $48 \mathrm{~h}$. The isolates were characterized and identified by using Gram staining and biochemical tests. After zobo production, one bottle from each set of sample in each group was randomly selected on day of production and every 2 weeks for eight weeks of the study for microbial and sensory analyses. About $1 \mathrm{~mL}$ of zobo juice from each sample was pipetted into 9 $\mathrm{mL}$ of peptone water and further diluted up to $10^{-3}$. Same plating method was used as previously described with the addition of Eosin-Methylene Blue agar (EMB) agar for enterobacteriaceae count.

\section{Sensory analysis}

Four sensory tests were performed (day 0,2,6 and 8 weeks of sample storage) at the Faculty of Agriculture, using ten untrained panelists cutting across students and staff at Bowen University. Different panelists were recruited every time to evaluate the various zobo juice samples. Refrigerated samples were taken out $3 \mathrm{~h}$ before the test in order to allow samples to normalize to room temperature before serving. A scoring test was used which was designed to determine which of the samples was most preferred. Water was provided to the panelist to cleanse their palate in between sample evaluation. Sensory attributes for scoring included appearance, aroma, taste (sweetness or tartness) and overall acceptability of the product. The samples were scored on a 5 point Hedonic scale where $1=$ dislike extremely, 2 = dislike moderately, $3=$ neither like nor dislike, $4=$ like moderately and $5=$ like very much (Meilgaard $\boldsymbol{e t}$ al., 1991). Sample code for sensory test and preparation ratios are presented in Table 1.

Table 1. Sensory codes and preparation ratios of preservative and zobo juice (w/v)

\begin{tabular}{lcc}
\hline Sample code & $\begin{array}{c}\text { Preservative-zobo juice ratio } \\
(\mathbf{w} / \mathbf{v})\end{array}$ & Sample name \\
\hline BBA & 0 g preservative: $1 \mathrm{~L}$ zobo & Control \\
BCA & Food vendor prepared zobo & FVPZ \\
CBA & 5 g moringa: $1 \mathrm{~L}$ zobo & $0.5 \% \mathrm{MZ}$ \\
CDB & 10 g moringa: $1 \mathrm{~L}$ zobo & $1 \% \mathrm{MZ}$ \\
ACC & 5 g ginger: $1 \mathrm{~L}$ zobo & $0.5 \% \mathrm{GZ}$ \\
ABD & 10 g ginger: $1 \mathrm{~L} \mathrm{zobo}$ & $1 \% \mathrm{GZ}$ \\
\hline
\end{tabular}

\section{Statistical Analysis}

Data collected from sensory tests were analyzed using Statistical Package for the Social Sciences (SPSS) (2011). Analysis of Variance (ANOVA) was used to evaluate significant differences and separation of the mean values was carried out using Duncan Multiple Range Test at $(\mathrm{p}<0.05)$.

\section{RESULTS}

\section{Physico-chemical analyse}

pH

The $\mathrm{pH}$ values of the different zobo samples immediately after preparation was higher for all the samples (BFP), compared to after pasteurization (AP) and further increased during storage for both samples stored at room and refrigeration temperatures as shown in Figures $1 \mathrm{a}$ and1b. There were statistical significan differences $(\mathrm{p}<0.05)$ among the samples. The average $\mathrm{pH}$ of the samples before pasteurization ranged from 2.44-2.75, with control as the lowest and food vendor prepared being the highest. After pasteurization $\mathrm{pH}$ dropped to 2.31-2.58 for control and FVPZ were lowest and highest. From week 4, there was an increase in pH FVPZ (4.12), control (4.07), while the increase in zobo with preservatives were not as high (Figure 1a). During storage there were similarities in $\mathrm{pH}$ trend for the samples stored at room and refrigeration temperatures. At room temperature, the $\mathrm{pH}$ of all the samples increased (Figure 1b).
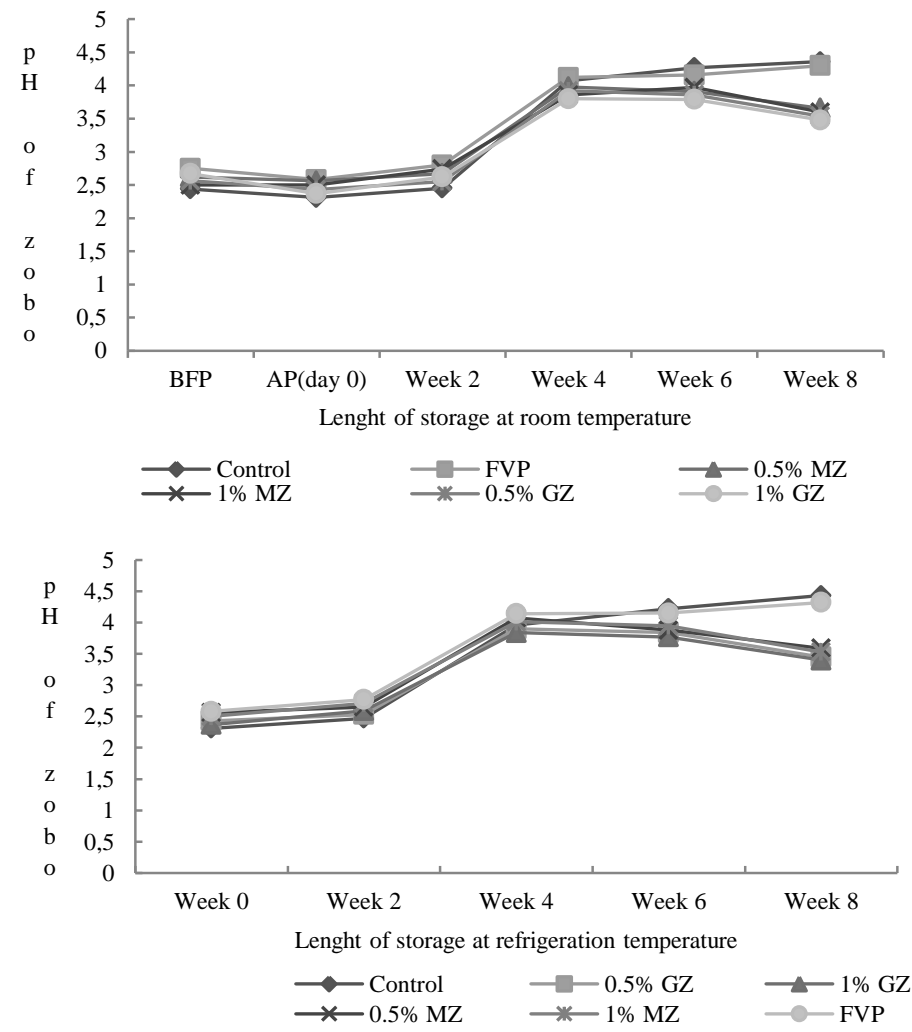

Figure $1 \mathrm{pH}$ of different zobo juice before and after pasteurization and storage at room (A) and refrigeration (B) Temperatures

\section{Total titratable acidity}

Total titratable acidity was performed on all the zobo juice samples. The results obtained are reported in Table 2 . In general, at week 0 , the \% Total titrable acidity ranged from .14 to $.21 \%$ for food vendor prepared zobo and $1 \% \mathrm{GZ}$ 
respectively. There were significant $(\mathrm{p}<0.05)$ statistical differences between the samples.

Table 2 Percentage Total titratable (\%TTA) analysis of zobo samples

\begin{tabular}{lcccccc}
\hline & \multicolumn{5}{c}{ Type of zobo } \\
\cline { 2 - 7 } $\begin{array}{l}\text { Length of } \\
\text { storage }\end{array}$ & Control & FVPZ & $0.5 \% \mathrm{MZ}$ & $1 \% \mathrm{MZ}$ & $0.5 \% \mathrm{GZ}$ & $1 \% \mathrm{GZ}$ \\
\hline Day 0 $(\%$ & $.20^{\mathrm{b}}$ & $.14^{\mathrm{d}}$ & $.20^{\mathrm{b}}$ & $.18^{\mathrm{c}}$ & $.20^{\mathrm{b}}$ & $.21^{\mathrm{a}}$ \\
TTA $)$ & \pm 0.02 & \pm 0.00 & \pm 1.05 & \pm 0.02 & \pm 0.03 & \pm 0.06 \\
\hline
\end{tabular}

Table 3 Mean ${ }^{1,2}$ Vitamin C content of control, food vendor prepared and zobo with ginger and moringa during storage

Storage condition

$\left(\mathrm{T}^{0} \mathrm{C}\right)$

\begin{tabular}{|c|c|c|c|c|c|c|}
\hline & Treatment & 0 & 2 & 4 & 6 & 8 \\
\hline \multirow{8}{*}{$\begin{array}{l}\text { Room } \\
\text { temperature } \\
\left(32 \pm 2{ }^{0} \mathrm{C}\right)\end{array}$} & Control & $24.7^{\mathrm{c}} \pm 0.03$ & $23.3^{\mathrm{c}} \pm 0.12$ & $23.1^{\mathrm{c}} \pm 0.02$ & $22.5^{\mathrm{c}} \pm 0.03$ & $20.3^{\mathrm{c}} \pm 0.05$ \\
\hline & FVPZ* ${ }^{1}$ & $24.4^{\mathrm{d}} \pm 0.15$ & $23.3^{\mathrm{c}} \pm 0.01$ & $23.1^{\mathrm{c}} \pm 0.03$ & $21.3^{\mathrm{c}} \pm 0.04$ & $21.0^{c} \pm 0.01$ \\
\hline & $0.5 \% \mathrm{MZ}^{* *}$ & $25.5^{\mathrm{b}} \pm 0.04$ & $25.5^{\mathrm{b}} \pm 0.06$ & $24.8^{b} \pm 0.03$ & $25.3^{b} \pm 0.10$ & $25.4^{\mathrm{b}} \pm 0.06$ \\
\hline & $1 \% \mathrm{MZ}$ & $25.7^{\mathrm{b}} \pm 0.04$ & $25.6^{\mathrm{b}} \pm 0.04$ & $24.6^{\mathrm{b}} \pm 0.16$ & $25.3^{b} \pm 0.03$ & $26.2^{\mathrm{b}} \pm 0.21$ \\
\hline & $0.5 \% \mathrm{GZ}^{*}$ & $26.7^{\mathrm{a}} \pm 0.10$ & $26.7^{\mathrm{a}} \pm 0.04$ & $26.4^{\mathrm{a}} \pm 0.07$ & $27.5^{\mathrm{a}} \pm 0.08$ & $29.8^{\mathrm{a}} \pm 0.03$ \\
\hline & $1 \% \mathrm{GZ}$ & $26.9^{\mathrm{a}} \pm 0.15$ & $26.9^{\mathrm{a}} \pm 0.03$ & $26.5^{\mathrm{a}} \pm 0.07$ & $27.7^{\mathrm{a}} \pm 0.03$ & $29.7^{\mathrm{a}} \pm 0.06$ \\
\hline & Control & $24.7^{\mathrm{c}} \pm 0.03$ & $24.7^{\mathrm{c}} \pm 0.03$ & $23.1^{\mathrm{c}} \pm 0.56$ & $22.6^{\mathrm{c}} \pm 0.01$ & $20.3^{\mathrm{c}} \pm 0.05$ \\
\hline & FVPZ & $24.4^{\mathrm{d}} \pm 0.15$ & $24.4^{\mathrm{c}} \pm 0.06$ & $23.1^{\mathrm{c}} \pm 0.05$ & $21.5^{\mathrm{c}} \pm 0.05$ & $21.0^{\mathrm{c}} \pm 0.01$ \\
\hline \multirow{4}{*}{$\begin{array}{l}\text { Refrigeration } \\
\text { temperature } \\
\left(10 \pm 2{ }^{0} \mathrm{C}\right)\end{array}$} & $0.5 \% \mathrm{MZ}$ & $25.5^{\mathrm{b}} \pm 0.04$ & $25.6^{\mathrm{b}} \pm 0.01$ & $24.8^{\mathrm{b}} \pm 0.01$ & $25.6^{\mathrm{b}} \pm 0.07$ & $25.4^{\mathrm{b}} \pm 0.06$ \\
\hline & $1 \% \mathrm{MZ}$ & $25.7^{\mathrm{b}} \pm 0.04$ & $25.7^{\mathrm{b}} \pm 0.01$ & $24.7^{b} \pm 0.02$ & $25.5^{\mathrm{b}} \pm 0.08$ & $26.2^{\mathrm{b}} \pm 0.21$ \\
\hline & $0.5 \% \mathrm{GZ}$ & $26.7^{\mathrm{a}} \pm 0.10$ & $26.8^{\mathrm{a}} \pm 0.09$ & $26.8^{\mathrm{a}} \pm 0.04$ & $27.7^{\mathrm{a}} \pm 0.03$ & $29.8^{\mathrm{a}} \pm 0.03$ \\
\hline & $1 \% \mathrm{GZ}$ & $26.9^{\mathrm{a}} \pm 0.15$ & $26.9^{\mathrm{a}} \pm 0.03$ & $26.3^{\mathrm{a}} \pm 0.27$ & $27.8^{\mathrm{a}} \pm 0.01$ & $29.7^{\mathrm{a}} \pm 0.06$ \\
\hline
\end{tabular}

$1=$ mean of three replicates, $2=$ means with same alphabets are not different $(\mathrm{p}<0.05)$ in each column, $3=$ Control $=$ zobo juice without ginger or moringa extract. * = Ginger zobo; **Moringa zobo; FVPZ*1= food vendor produced zobo.

\section{MICROBIAL ANALYSIS}

\section{Microbial quality of raw material}

In order to assess the microbial quality of the raw materials (Roselle calyces, ginger, moringa, and sugar) used in the preparation of zobo juice, were subjected to microbial analysis and the results are shown in Table 4. Overall there were growths in the different agars used, indicating that all the raw materials were contaminated. Ginger had the highest total viable count of too numerous to count

\section{Vitamin C}

As reported in Table 3, for week 0, zobo juice with ginger had the highest ascorbic acid content. Juice with $1 \%$ ginger had $(26.9 \mathrm{mg} / 100 \mathrm{ml})$ while $0.5 \%$ ginger had $(26.7 \mathrm{mg} / 100 \mathrm{ml})$ and were significantly different from other samples. Throughout the period of storage at room $\left(32 \pm 2{ }^{0} \mathrm{C}\right)$ and refrigerator $\left(10 \pm 2{ }^{0} \mathrm{C}\right)$ temperatures ascorbic contents remained high and even increased for the zobo juices with preservatives while it was lower for control and FVPZ. Ginger preserved zobo consistently had higher ascorbic content than Moringa preserved zobo. Vitamin $\mathrm{C}$ content in

the preserved drinks during storage either increased or remained at the value in week 0 .

Vitamin C content $(\mathrm{mg} / 100 \mathrm{ml})$ during storage in weeks

(TNTC); sugar had highest staphylococcal count $\left(3.0 \times 10^{4} \mathrm{CFU} / \mathrm{g}\right)$, and moringa had $\left(8.0 \times 10^{4} \mathrm{CFU} / \mathrm{g}\right)$ and highest fungal count.

Overall, four genera of microorganisms were isolated and identified from the raw material. These were namely Staphylococcus aureus (Gram positive cocci, catalase positive and positive mannitol fermentation), Bacillus subtilis (Gram positive rods, catalase positive and starch hydrolysis positive) and Saccharomyces cerevisiae were from ginger, moringa and Roselle. Additionally, Micrococcus spp. (Gram positive cocci, catalase positive and negative growth on mannitol agar), was also isolated from sugar.

Table 4 Microbial load of raw materials used in the preparation of zobo juice

Raw material

Microbial load (CFU/g*) of raw material

\begin{tabular}{llll}
\cline { 2 - 3 } & $\begin{array}{l}\text { Total Viable } \\
\text { Count }\end{array}$ & $\begin{array}{l}\text { Staphylococcal } \\
\text { spp. }\end{array}$ & Total Fungal Count \\
\hline Powdered ginger & TNTC** & $1.0 \times 10^{4}$ & $\mathrm{NG}^{1}$ \\
Powdered Moringa & $9.2 \times 10^{4}$ & $3.0 \times 10^{3}$ & $8.0 \times 10^{4}$ \\
Sugar & $9.2 \times 10^{4}$ & $3.0 \times 10^{4}$ & $7.7 \times 10^{4}$ \\
Powdered H. sabdariffa & $7.8 \times 10^{4}$ & $2.5 \times 10^{4}$ & $5.6 \times 10^{4}$ \\
\hline CFU/g* = Colony forming unit per gram of sample; TNTC*** Too numerous to count; $\mathrm{NG}^{1}=$ No growth
\end{tabular}

\section{Microbial quality of different zobo juice samples}

Results of the microbial load of zobo juice with or without preservative and food vendor prepared are presented in Tables 3 - 6. Day 0 microbial load was performed after cooling but before pasteurization. The total viable count (TVC) on production day was too numerous to count for all the different zobo juice samples except $0.5 \% \mathrm{GZ}\left(2.2 \times 10^{3} \mathrm{CFU} / \mathrm{mL}\right)$ (Table 5). Continual increase in count ranging from $\left(2.3 \times 10^{5} \mathrm{CFU} / \mathrm{mL}\right.$ to TNTC) was observed throughout the period of storage for control and food vendor prepared zobo (FVPZ) while in zobo with preservatives, TVC reduced ranging from $\left(5.0 \times 10^{2}\right.$ to $2.0 \times 10^{5}$ to $1.5 \times 10^{3}$ to $8.5 \times 10^{3}$ ) for weeks $2,4,6$ and 8 of storage. There were significant differences in counts between week 4 and weeks 6 and 8 of storage, indicated by the 2-3 log reduction. Refrigerated samples had slightly lower TVC during storage and it was observed that $1 \%$ ginger was slightly more effective in reducing total viable count. Staphylococcal counts are reported in Table 6. FVPZ had the highest count $\left(8.0 \times 10^{4} \mathrm{CFU} / \mathrm{mL}\right)$ on production day and throughou storage. Juice with preservative $(0.5-1 \%)$ inclusion did not have growth on day 0 except $1 \%$ moringa $\left(3.0 \times 10^{2} \mathrm{CFU} / \mathrm{mL}\right)$. The natural preservatives were able to keep staphylococcal growth in check during the eight weeks of storage while FVPZ and control zobo continued to show increased count. Refrigeration did not appear to reduce staphylococcal count until week 8 of storage indicated by (NG) in all the preserved zobo. There was no growth on EMB agar for day 0, probably because of the high temperature employed in preparing the zobo juice which may have resulted in microbial stress. Throughout storage period, only lactose negative enterobacteriaceae was observed and enumerated in all the juice samples. At week 2 of storage, $0.5 \% \mathrm{GZ}$ had the highest count $\left(3.0 \times 10^{3}\right)$, but at week eight there was 0 count while the control $\left(1.5 \times 10^{2}\right.$ to $\left.1.4 \times 10^{3}\right)$ and FVPZ $\left(2.1 \times 10^{3}\right.$ to $\left.1.4 \times 10^{3}\right) \mathrm{CFU} / \mathrm{mL}$ were high for room and refrigerated samples (Table 7). It was also observed that storing the zobo samples at refrigeration temperature resulted in lower count, and that the ginger extract was more effective than moringa in reducing enterobacteriaceae count. Total fungal count was high on the production day with $0.5 \% \mathrm{GZ}$ having the highest load $\left(5.6 \times 10^{4}\right)$ but subsequently reduction in count was observed at weeks 2, 4, 6 and 8 except the food vendor prepared zobo (Table 8). 
$\underline{\text { Table 5Total viable count }}(\mathrm{CFU} / \mathrm{mL})$ of control, food vendor prepared and treated zobo juice during storage

Total Viable count CFU/ mL during period of storage

\begin{tabular}{|c|c|c|c|c|c|}
\hline \multirow{2}{*}{ Samples } & \\
\hline & Day 0 & Week 2 & Week 4 & Week 6 & Week 8 \\
\hline \multicolumn{6}{|c|}{ Rm Temp $\left(32 \pm 2^{0} \mathrm{C}\right)$} \\
\hline Control & TNTC $^{2}$ & TNTC & TNTC & TNTC & TNTC \\
\hline $\mathrm{FVPZ}^{1}$ juice & TNTC & TNTC & TNTC & TNTC & TNTC \\
\hline $0.5 \% \mathrm{MZ}^{*}$ juice & TNTC & $1.2 \times 10^{3}$ & $2.0 \times 10^{5}$ & $1.5 \times 10^{3}$ & $1.5 \times 10^{3}$ \\
\hline $1 \% \mathrm{MZ}$ juice & TNTC & $5.0 \times 10^{3}$ & $1.8 \times 10^{5}$ & $1.2 \times 10^{3}$ & $1.3 \times 10^{3}$ \\
\hline $0.5 \% \mathrm{GZ} * *$ juice & $2.2 \times 10^{3}$ & $1.1 \times 10^{3}$ & $1.3 \times 10^{5}$ & $1.5 \times 10^{3}$ & $9.4 \times 10^{2}$ \\
\hline $1 \%$ GZ juice & TNTC & $2.0 \times 10^{3}$ & $1.2 \times 10^{5}$ & $1.3 \times 10^{3}$ & $8.5 \times 10^{3}$ \\
\hline \multicolumn{6}{|c|}{ Chilling Temp $\left(10 \pm 2^{0} \mathrm{C}\right)$} \\
\hline Control & TNTC & TNTC & $2.3 \times 10^{5}$ & TNTC & TNTC \\
\hline FVPZ juice & TNTC & TNTC & TNTC & TNTC & TNTC \\
\hline $0.5 \% \mathrm{MZ}$ juice & TNTC & $1.0 \times 10^{3}$ & $2.0 \times 10^{5}$ & $1.5 \times 10^{3}$ & $1.2 \times 10^{3}$ \\
\hline $1 \% \mathrm{MZ}$ juice & TNTC $2.2 \times 10^{3}$ & $5.0 \times 10^{2}$ & $1.5 \times 10^{3}$ & $1.2 \times 10^{3}$ & $1.2 \times 10^{3}$ \\
\hline $0.5 \% \mathrm{GZ}$ juice & TNTC & $1.2 \times 10^{3}$ & $1.1 \times 10^{5}$ & $1.1 \times 10^{3}$ & $8.6 \times 10^{2}$ \\
\hline $1 \%$ GZ juice & & $1.2 \times 10^{3}$ & $1.2 \times 10^{5}$ & $1.2 \times 10^{3}$ & $8.0 \times 10^{2}$ \\
\hline
\end{tabular}

Table 6 Staphylococcal count ${ }_{(\mathrm{CFU} / \mathrm{mL})}$ of control, food vendor prepared and treated zobo juice during storage

\begin{tabular}{|c|c|c|c|c|c|}
\hline \multirow{2}{*}{ Samples } & \multicolumn{5}{|c|}{ Staphylococcal count CFU/ mL during period of storage } \\
\hline & Day 0 & Week 2 & Week 4 & Week 6 & Week 8 \\
\hline \multicolumn{6}{|c|}{ Rm Temp (32 $\left.\pm 2^{0} \mathrm{C}\right)$} \\
\hline Control & $4.5 \times 10^{4}$ & $1.6 \times 10^{2}$ & $1.6 \times 10^{2}$ & $3.5 \times 10^{2}$ & $9.5 \times 10^{2}$ \\
\hline FVPZ juice & $8.0 \times 10^{4}$ & TNTC & $3.2 \times 10^{2}$ & $7.8 \times 10^{2}$ & $9.8 \times 10^{3}$ \\
\hline $0.5 \% \mathrm{MZ}$ juice & NG & $3 \times 10^{1}$ & $1.9 \times 10^{2}$ & $1.5 \times 10^{2}$ & $3.5 \times 10^{3}$ \\
\hline $1 \% \mathrm{MZ}$ juice & $3.0 \times 10^{2}$ & $1.1 \times 10^{2}$ & NG & $6.0 \times 10^{1}$ & $8.0 \times 10^{1}$ \\
\hline $0.5 \%$ GZ juice & $\mathrm{NG}^{\mathrm{a}}$ & NG & $1.2 \times 10^{2}$ & NG & $1.0 \times 10^{2}$ \\
\hline $1 \%$ GZ juice & NG & NG & $1.3 \times 10^{2}$ & $1 \times 10^{1}$ & NG \\
\hline \multicolumn{6}{|c|}{ Chilling Temp $\left(10 \pm 2^{0} \mathrm{C}\right)$} \\
\hline Control & $4.5 \times 10^{4}$ & $1.0 \times 10^{2}$ & $2.2 \times 10^{2}$ & $1.8 \times 10^{2}$ & $8.1 \times 10^{2}$ \\
\hline FVPZ juice & $8.0 \times 10^{4}$ & $1.5 \times 10^{2}$ & $8.0 \times 10^{2}$ & $1.2 \times 10^{3}$ & $1.0 \times 10^{3}$ \\
\hline $0.5 \% \mathrm{MZ}$ juice & NG & NG & $1.4 \times 10^{2}$ & $1.5 \times 10^{2}$ & NG \\
\hline $1 \% \mathrm{MZ}$ juice & $3.0 \times 10^{2}$ & $4.0 \times 10^{1}$ & NG & $1.4 \times 10^{2}$ & NG \\
\hline $0.5 \%$ GZ juice & NG & NG & $1.4 \times 10^{2}$ & $6 \times 10^{1}$ & NG \\
\hline $1 \%$ GZ juice & NG & NG & $9.0 \times 10^{1}$ & $6 \times 10^{1}$ & NG \\
\hline
\end{tabular}

$\mathrm{GZ}=$ ginger zobo; $\mathrm{MZ}=$ moringa zobo $;{ }^{1} \mathrm{FVPZ}=$ food vendor produced zobo. $\mathrm{TNTC}=$ too numerous to count; $\mathrm{NG}^{\mathrm{a}}=$ no growth

Table 7 Enterobacteriaceae count $(\mathrm{CFU} / \mathrm{mL})$ of control, food vendor prepared and treated zobo juice during storage

Samples

\begin{tabular}{|c|c|c|c|c|c|}
\hline \multirow{2}{*}{ Samples } & & & & & \\
\hline & Day 0 & Week 2 & Week 4 & Week 6 & Week 8 \\
\hline \multicolumn{6}{|c|}{ Rm Temp (32 $\left.\pm 2^{0} \mathrm{C}\right)$} \\
\hline Control & NG & $1.0 \times 10^{3}$ & $3.6 \times 10^{2}$ & $1 \times 10^{3}$ & $1.5 \times 10^{2}$ \\
\hline FVPZ juice & NG & $1.4 \times 10^{3}$ & $2.0 \times 10^{2}$ & $1.3 \times 10^{3}$ & $2.1 \times 10^{3}$ \\
\hline $0.5 \% \mathrm{MZ}$ juice & NG & $1.0 \times 10^{3}$ & $9.6 \times 10^{2}$ & $2.5 \times 10^{2}$ & $8.0 \times 10^{2}$ \\
\hline $1 \% \mathrm{MZ}$ juice & NG & $\mathrm{NG}^{\mathrm{a}}$ & $4.3 \times 10^{2}$ & $2.3 \times 10^{2}$ & $1.0 \times 10^{2}$ \\
\hline $0.5 \%$ GZ juice & NG & $3 \times 10^{3}$ & $1.8 \times 10^{3}$ & $8 \times 10^{1}$ & NG \\
\hline $1 \%$ GZ juice & NG & $\mathrm{NG}^{\mathrm{a}}$ & $2.0 \times 10^{2}$ & NG & NG \\
\hline \multicolumn{6}{|c|}{ Chilling Temp $\left(10 \pm 2^{0} \mathrm{C}\right)$} \\
\hline Control & NG & NG & $6.0 \times 10^{1}$ & $8.0 \times 10^{2}$ & $1.4 \times 10^{3}$ \\
\hline FVPZ juice & NG & $1.0 \times 10^{1}$ & $2.6 \times 10^{2}$ & $2.0 \times 10^{2}$ & $1.4 \times 10^{3}$ \\
\hline $0.5 \% \mathrm{MZ}$ juice & NG & $\mathrm{NG}^{\mathrm{a}}$ & $1.1 \times 10^{2}$ & $1.5 \times 10^{2}$ & NG \\
\hline $1 \% \mathrm{MZ}$ juice & NG & $4.0 \times 10^{1}$ & $8.0 \times 10^{1}$ & $1.4 \times 10^{2}$ & NG \\
\hline $0.5 \%$ GZ juice & NG & $\mathrm{NG}^{\mathrm{a}}$ & $1.1 \times 10^{2}$ & $1 \times 10^{1}$ & NG \\
\hline $1 \%$ GZ juice & NG & $N^{a}$ & $6.0 \times 10^{1}$ & NG & NG \\
\hline
\end{tabular}

Table 8 Fungal count ${ }_{(\mathrm{CFU} / \mathrm{mL})}$ of control, food vendor prepared and treated zobo juice during storage

Total fungal count $\mathrm{CFU} / \mathrm{mL}$ during period of storage

\begin{tabular}{|c|c|c|c|c|c|}
\hline Samples & Day 0 & Week 2 & Week 4 & Week 6 & Week 8 \\
\hline Rm Temp (32 \pm & & & & & \\
\hline Control & $4.0 \times 10^{4}$ & $7.0 \times 10^{2}$ & $7.1 \times 10^{2}$ & $2.4 \times 10^{3}$ & $2.4 \times 10^{3}$ \\
\hline FVPZ juice & $4.0 \times 10^{4}$ & $7.6 \times 10^{2}$ & TNTC & TNTC & TNTC \\
\hline $0.5 \% \mathrm{MZ}$ juice & $5.0 \times 10^{4}$ & $5.2 \times 10^{2}$ & $5.2 \times 10^{2}$ & $4.4 \times 10^{3}$ & $\mathrm{NG}^{\mathrm{a}}$ \\
\hline $1 \% \mathrm{MZ}$ juice & $4.0 \times 10^{4}$ & $5.0 \times 10^{2}$ & $8.4 \times 10^{2}$ & $4.6 \times 10^{3}$ & NG \\
\hline $0.5 \%$ GZ juice & $5.6 \times 10^{4}$ & $4.0 \times 10^{2}$ & $6.4 \times 10^{2}$ & NG & NG \\
\hline $1 \%$ GZ juice & $5.5 \times 10^{4}$ & $3.6 \times 10^{2}$ & $5.5 \times 10^{2}$ & NG & NG \\
\hline \multicolumn{6}{|c|}{ Chilling Temp $\left(10 \pm 2^{0} \mathrm{C}\right)$} \\
\hline Control & $4.0 \times 10^{4}$ & $3.0 \times 10^{2}$ & $1.9 \times 10^{3}$ & $2.4 \times 10^{3}$ & $2.5 \times 10^{3}$ \\
\hline FVPZ juice & $4.0 \times 10^{4}$ & $7.0 \times 10^{2}$ & TNTC & TNTC & TNTC \\
\hline $0.5 \% \mathrm{MZ}$ juice & $5.0 \times 10^{4}$ & $4.7 \times 10^{2}$ & $2.7 \times 10^{3}$ & NG & $3.4 \times 10^{2}$ \\
\hline $1 \% \mathrm{MZ}$ juice & $4.0 \times 10^{4}$ & NG & $1.5 \times 10^{3}$ & $5.2 \times 10^{2}$ & $1.2 \times 10^{2}$ \\
\hline $0.5 \%$ GZ juice & $5.6 \times 10^{4}$ & $4.0 \times 10^{2}$ & $1.4 \times 10^{3}$ & NG & NG \\
\hline $1 \%$ GZ juice & $5.5 \times 10^{4}$ & NG & $7.6 \times 10^{3}$ & NG & NG \\
\hline
\end{tabular}




\section{SENSORY EVALUATION ANALYSIS}

Sensory evaluation of the quality attributes of the various zobo samples were carried out on production day and every two weeks of storage for eight weeks except week four. Of the total number of panelists (40) who participated in sensory analysis, there were $24(60 \%)$ females and $9(22.5 \%)$ males, of which 13 $(32.5 \%)$ were in age range of $18-19$ and $19(47.5 \%)$ were $20-30$ years old

Scores of appearance, aroma, taste and general acceptability of the juice on production day and during storage are presented in Figures 2- 5. For appearance, BCA (FVPZ) had higher degree of liking of (4.5) and the lowest was for $1 \% \mathrm{GZ}$ (3.8) on day 0 . However during storage (FVPZ) and control (BBA) deteriorated in appearance $(1.5-2.2)$ but preserved zobo scored higher ranging from (4.4 4.7). Similar trend was observed for aroma FVPZ (4.5), control and (ABD) $1 \% \mathrm{GZ}$ (3.9) were the highest and lowest respectively on day 0. During storage BCA and BBA were scored lower and preserved zobo higher (Figure 3). ACC was scored higher in all attributes except taste at refrigeration temperature 2 weeks after storage (Figure 3). In taste and general acceptability, BCA had (4.4) and (4.7) on day 0 , compared to other zobo samples but lost likeability during storage (Figures 4 and 5). There were significant differences $(p<0.05)$ between BCA (FVPZ) and BBA (control), ABD (1\%GZ) CBA (0.5\%MZ) and CDB $(1 \% \mathrm{MZ})$ in taste and overall acceptability. At 6 and 8 weeks of storage zobo samples with ginger $\mathrm{ACC}$ and $\mathrm{ABD}$ had high general acceptability/likeability scores (4.6 and 4.5) while BCA and BBA (1.8 and 1.4) quality were scored very low as presented in Figure 5. Taste tests of BCA and BBA were not performed at weeks 6 and 8 , because of the appearance and aroma of the juice and food safety concern.
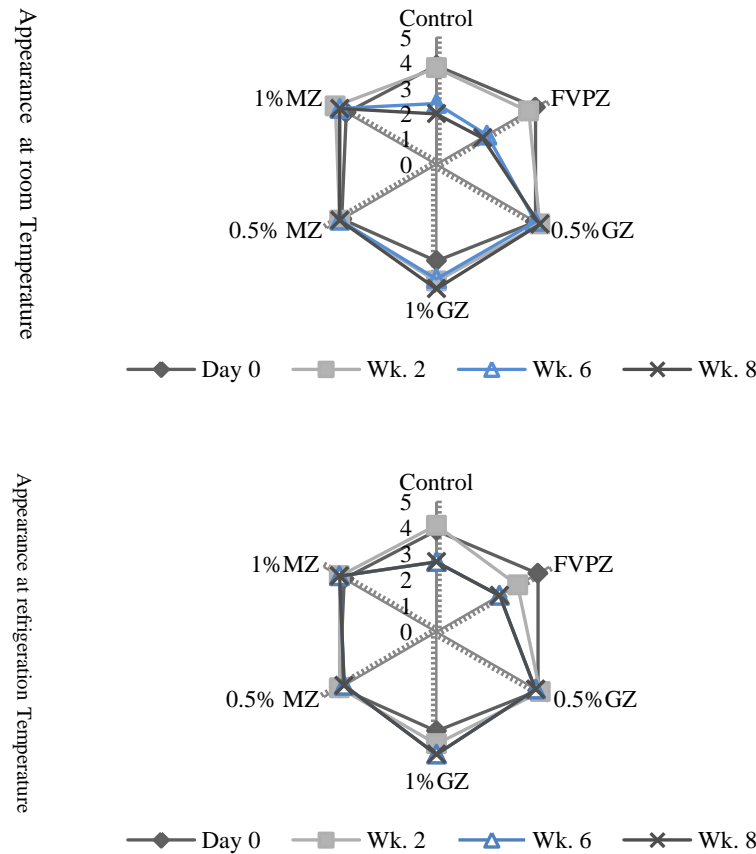

Figure 2 Appearance scores of zobo juice during storage at room (A) and refrigeration $(\mathrm{B})$ temperatures.

$\mathrm{BBA}=$ control, $\mathrm{BCA}=\mathrm{FVPZ}, \mathrm{CBA}=0.5 \% \mathrm{MZ}, \mathrm{CDB}=1 \% \mathrm{MZ}, \mathrm{ACC}=$ $0.5 \% \mathrm{GZ}, \mathrm{ABD}=1 \% \mathrm{GZ}$

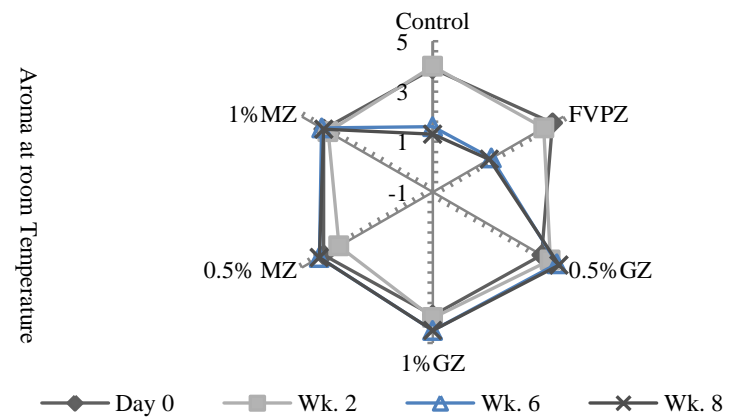

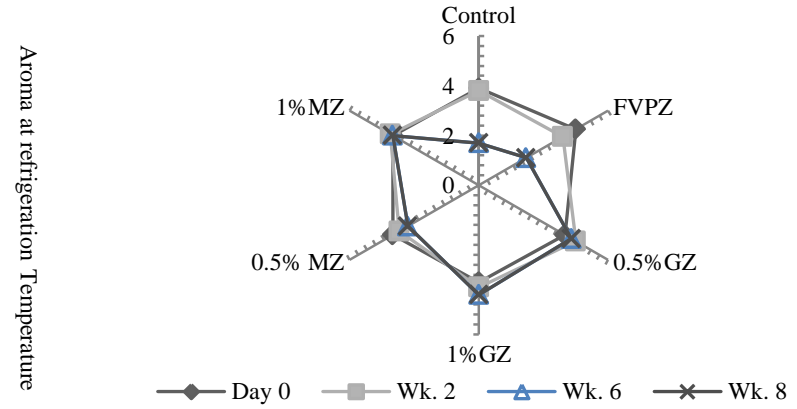

Figure 3 Aroma scores of zobo juice during storage at room (A) and refrigeration (B) temperatures.
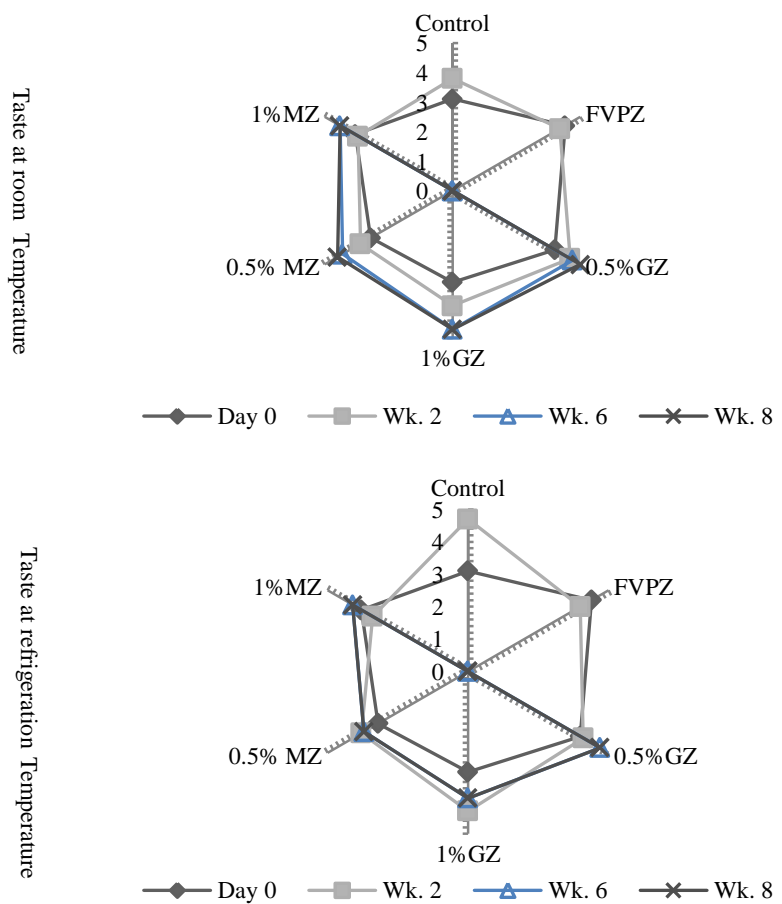

Figure 4. Taste scores of zobo juice during storage at room (A) and refrigeration (B) temperatures
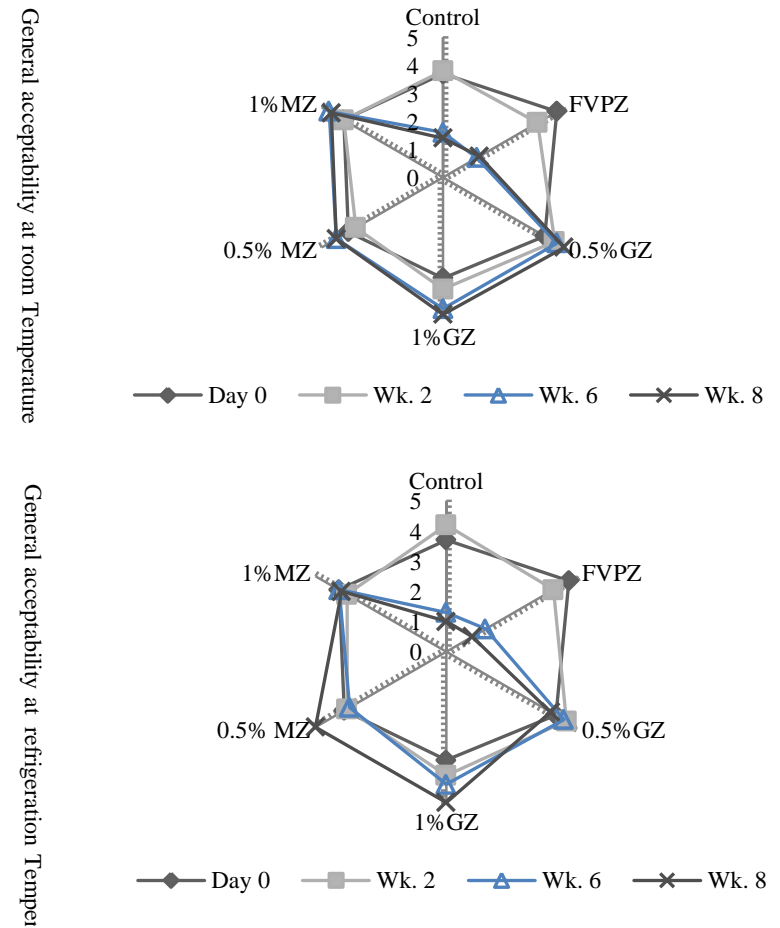

Figure 5 General acceptability scores of zobo juice during storage at room and refrigeration temperatures. 


\section{DISCUSSION}

The $\mathrm{pH}$ results in this study is within range of other studies indicating that zobo drink is acidic in nature (Doughari et al., 2008; Omemu et al., 2006; Ifie et al., 2012) but contradicts (6.63) and (7.05) values of Adesokan et al., (2013). Low $\mathrm{pH}$ value of 3.0 has been reported to be suitable for preservation of zobo juice (Omemu et al., 2006). Furthermore, according (Leahu et al., 2013), orange juice has a $\mathrm{pH}$ of 3.30-3.82, pineapple juice 3.30-3.60 and grapefruit juice 2.90-3.25 and these fruit juices fall within the range of high acid foods. According to Frazier and Westhoof (1988), zobo juice belongs to a class of foods referred to as high acid foods. High acid foods do not support survival of many pathogenic organisms but favours the proliferation of acidic organisms. The results of $\%$ TTA is low, low titratable acidity is also reported by Bolade $\boldsymbol{e t}$ al., (2009), and it was attributed to low $\mathrm{pH}$ value and the status of zobo not being a product of fermentation. The vitamin $\mathrm{C}$ content in this study is within the range of (17.2 to $30.7 \mathrm{mg} / 100 \mathrm{ml}$ ) reported by Bolade $\boldsymbol{e t}$ al., (2009). Furthermore, $\mathrm{pH}$ is the main factor affecting the stability of vitamin $\mathrm{C}$, consequently high values of $\mathrm{pH}$ favour the oxidation processes of vitamin $\mathrm{C}$ (Leahu et al., 2013). Although Hibiscus sabdariffa has been documented to have antioxidants (Oboh and Okhai, 2012) the addition of moringa and ginger also contributed to the antioxidant content Hence the preserved zobo drinks were able to withstand oxidation and prevent degradation of vitamin $\mathrm{C}$ during storage. The result also show that was no significant difference among the zobo drinks stored at room and refrigerator temperatures.

The total viable count for Roselle exceeds the allowable limit of $<10,000 \mathrm{CFU} / \mathrm{g}$ set by export markets (FAO, 2004). The high incidence of contamination could be due to poor harvesting and handling techniques, unclean containers, such as the bowls in which the raw materials were stored before sale, poor sanitary and largely unhygienic storage conditions and un-kept environment, where the raw materials are sold (Ehiri $\boldsymbol{e t}$ al., 2001). Microorganisms isolated from the raw materials included Bacillus subtilis, Staphylococcus aureus, Micrococcus spp. and Saccharomyces cerevisiae. The majority of these microorganisms are norma plant microflora and inhabitant of the soil or they contaminate the material by human action. Other studies have also reported isolation of these microorganisms from the raw materials (Nwafor and Ikenebomeh, 2009; Egbere et al., 2007) Furthermore, some of the microorganisms isolated are persistent because they are able to withstand harsh environmental conditions and have ability to form spores (Pelczar et al., 1993). At the initial day of zobo preparation, total viable, staphylococcal and fungal counts were high. Although, according to Frazier and Westhoff, (1988), the microbial loads for all the zobo juice samples were within the limits of $\left(10^{5} \mathrm{CFU} / \mathrm{mL}\right)$ for ready to consume food products. The presence of Staphylococcus aureus is indicative of poor personal hygiene conditions or excessive handling of the beverage (Ajayi and Oluwoye, 2015) and is of concern particularly because of multidrug resistant strains. It is noteworthy that enteric microorganisms were not recovered from the raw materials and on day 0 but were subsequently isolated from the juice during storage. Since common intestinal microorganisms particularly pathogens are readily inactivated by heat, it is possible that boiling may have inactivated the enteric microorganisms. Furthermore, temperatures above $60{ }^{\circ} \mathrm{C}$ for a few minutes have been documented to be sufficient to kill enteric microorganisms (Backer, 2012). Also, according to Noor et al. (2013), increase in temperature cause stress to microorganisms by denaturing their proteins. During storage of zobo, only non-lactose fermenter enterobacteriaceae were isolated and enumerated and is in agreement with the report by Omemu et al., (2006), and could be from the water used in preparation. There were fluctuations in the microbial load of the juice during storage that may coincide with microbial growth phase and effect of the preservatives. For example, a decrease in count was observed during week 2 of storage, and then an increase in count was observed at week 4 . Then reduction in counts was observed at weeks 6 and 8. Similar trends of increase in microbial counts observed in this study were also reported by Omemu et al., (2006) and Ogiehor et al., (2008). Reduction of microbial load was also reported by Egbere et al. (2007) and Doughari et al. (2008) using chemical preservatives.

At week 8 there was a decrease in microbial load in all of the samples except the control sample and food vendor prepared zobo juice at both ambient and refrigeration temperatures. Decrease in microbial load observed in the samples that contained 0.5 and $1 \%$ ginger and moringa may be related to the antimicrobial effects and phytochemicals shogaol and zingerol present in ginger (Kolapo et al. 2007). Also, Singh et al. (2009) reported the presence of gallic acid, chlorogenic acid, ellagic acid, ferulic acid, kaempferol, quercetin and vanillin glycosides, phenols, sterols, flavanol glycosides from the aqueous extracts of leaves, fruits and seeds of $M$. oliefera which may be responsible for the antimicrobial effects in zobo juice. Furthermore, Moringa olifera seeds contain isothiocynates which are documented to have antimicrobial properties (Padla et al., 2012). Similar findings of microbial load reduction have been documented for related food items such as palm wine (Ogiehor $\boldsymbol{e t}$ al., 1998) and African oil bean seed (Ogbulie $\boldsymbol{e}$ al., 1993). Microbial counts of the different types of zobo juice were further reduced during storage when combined with refrigeration. For example, at week 8 of storage, juice with preservatives had reduced TVC $\left(8.0 \times 10^{2}\right.$ to $1.2 \times 10^{3}$ $\mathrm{CFU} / \mathrm{mL}$ ); staphylococcal (NG); enterobacteriaceae (NG); and fungal counts ranged from $\left(\mathrm{NG}\right.$ to $3.4 \times 10^{2}$ ). Reduction in microbial count during refrigeration was also reported by (Fasoyiro et al., 2005; Ogiehor et al., 2008). The decrease in microbial load of samples stored at refrigeration temperature may be the synergistic effects of boiling, addition of ginger or moringa, pasteurization and low temperature on the associated microorganisms in the juice. This helped to minimize the microbial activities by creating barriers which the microorganisms present were unable to overcome (Ogiehor et al., 2008). Refrigeration in combination with preservative agents helps to stabilize the microbial, nutritive quality (Ogiehor et al., 2008) and extend the shelf life of the zobo juice. Similar findings have been reported for related indigenous and novel food items such as palm wine, apku and zobo (Ogiehor et al., 1998; Ogiehor et al., 2004; Ogiehor, et al., 2008). The shelf life of zobo juice is less than three days without any form of preservatives (Samy, 1980). The utilization of moringa as a preservative in zobo juice is a novel idea that can be further explored. Albeit the control sample and food vendor prepared zobo juice were also subjected to pasteurization, the microbial loads were higher due to the absence of preservatives in the samples at both storage conditions as recorded in Tables 3-6.

At the onset of the study food vendor prepared zobo was preferred in all attributes but as storage continued, deterioration in sensory quality was observed as the food vendor prepared zobo and control were slimy and have strong fermentative (sour and alcoholic) aroma. Refrigeration did not impact the sensory attributes scores in this study, although it has been documented that low temperature can be used to reduce microbial activity in foods (Ogiehor, 2007; Ray and Bhunia, 2014). An increase in volatile components when samples are heated has been reported by Atkins and Locke, (2002), resulting in more intense odour (Voirol and Daget, 1989) and influencing sensory attributes. Delwiche (2004), reported that food sample might contain volatile compounds that are below threshold levels at lower temperatures, which might explains why zobo samples stored at refrigerated temperature scored lower than room temperature in aroma and taste during weeks 6 and 8 . Inclusion of natural preservatives (moringa or ginger) contributed to maintaining the sensory attributes such as appearance, aroma, taste and acceptability of the juice.

\section{CONCLUSION}

Some physico-chemical qualities of zobo juice stored at room or refrigerated temperatures for eight weeks were analyzed. During storage, $\mathrm{pH}$ of all the juice samples increased, but control and food vendor prepared juice increased more than the preserved juice and also there were significant losses in vitamin $\mathrm{C}$ content. However, the juice samples with preservatives were able to keep $\mathrm{pH}$ in check, thereby limiting loss of vitamin C. Microbial analysis report of the raw materials used in producing zobo show contamination with a variety of microorganisms such as Staphylococcus, Bacillus subtilis, Micrococcus and Saccharomyces cerevisiae. Addition of moringa or ginger extracts ( 0.5 and $1 \%)$ to zobo juice alone and in combination with refrigeration proffered resistance to the growth of microorganism, thereby reducing the total viable, enterobacteriaceae, staphylococcal, and fungal counts. Lower microbial counts extended the shelf life of the juice to 8 weeks. Ginger extract showed more effectiveness against microorganisms in zobo than moringa extract. From sensory qualities (appearance, aroma, taste and overall acceptability), panelists scored ginger spiced $(0.5-1 \%)$ zobo higher during storage period in the attributes analyzed and is able to maintain the sensory qualities better than moringa zobo, zobo without preservatives and food vendor prepared zobo.

\section{REFERENCE}

ADEGUNLOYE, B. J., OMONIYI, J. O., OWOLABI, O. A., AJAGBONNA, O P., SOFOLA, O. A., COKER, H. A. (1996). Mechanism of the blood pressure lowering effect of the calyx extract of Hibiscus sabdariffa in rats. African Journal of Medical Science, 25(3): 235-238.

ADESOKAN, I. A., ABIOLA, O. P., ADIGUN, M. O., ANIFOWOSE, O. A (2013). Analysis of quality attributes of Hibiscus sabdariffa (zobo) drinks blended with aqueous extract of ginger and garlic. African Journal of Food Science, 7(7): 174-177. http://dx.doi.org/10.5897/AJFS12.152

AJAYI, O. A., OLUWOYE, J. O. (2015). Sustainable street vended foods and food safety: a conceptual framework. International Journal Food Safety, Nutrition and Public Health, 5(3/4): 195-216. http://dx.doi.org/10.1504/IJFSNPH.2015.070154

AKANYA, H. O., OYELEKE, S. B., LAWAL, F. F. (1997). Analysis of Sorre Drink. Nigerian Journal Biochemical Molecular Biology, 12: 77-81.

AOAC (1990). Official Methods of Analysis of the Association of Official Analytical Chemists. 15th Ed. Arlington, Va.

ASHOK, K., PARI, L. (2003). Antioxidant action of Moringa oleifera Lam. (drumstick) against antitubercular drugs induced lipid peroxidation in rats. $\begin{array}{llll}\text { Journal of Medical } & \text { Food, } & \text { 6(3):255-259 }\end{array}$ http://dx.doi.org/10.1089/10966200360716670

ATKINS, P. W., LOCKE, J. W. (2002). Atkins' physical chemistry. New York: Oxford University Press

BACKER, H. D. (2012). Water Disinfection for Travelers. Available at http://wwwnc.cdc.gov/travel/yellowbook/2016/the-pre-travel-consultation/waterdisinfection-for-travelers. Accessed August $22^{\text {nd }} 2015$. 
BEDIN, C., GUTKOSKI, S. B., WIEST, J. M. (1999). Atividade antimicrobiana das especiarias. Higiene Alimentar, 13, 26-29.

BELLO, O. O., ADELEKE, O. (2012). Antimicrobial Effects of Spices on Spoilage Organisms of MoinMoin. Advances in Bioresearch, 3 (2): 60 - 65.

BOLADE, M. K., OLUWALANA I. B., OJO, O. (2009). Commercial practice of Roselle (Hibiscus sabdariffa L.) beverage production: optimization of hot water extraction and sweetness level. World Journal of Agricultural Sciences, 5(1): 126-131.

BRAIDE, W., ORANUSI, S., PETER-IKECHUKWU, A. I. (2012). Perspectives in the hurdle techniques in the preservation of a non- alcoholic beverage, zobo. African Journal of Food Science and Technology, 3(2):46-52.

BUKAR, A., UBA, A., KAWO, A. H. (2011). Preservative effect of Moringa oleifera Lam seed extract on bread. Savannah Journal of Agriculture, 6(2):62 66.

CACERES, A., LOPEZ, S. (1991). Pharmacologic properties of M. oleifera: 3 : Effect of seed extracts in the treatment of experimental Pyodermia. Fitoterapia, 62:449-450

CLYDESCALE, F. M., MAIN, J. H., FRANCIS, F. J. (1979). Roselle (Hibiscus sabdariffa) anthocyanin as colourants for beverages and gelatin deserts. Journal of Food Protection, 42: 204-267.

DELWICHE, J. (2004). The impact of perceptual interactions on perceived flavour. Food Quality and Preference 15: 137-146.

DOUGHARI, J. H., ALABI, G., ELMAHMOOD, A. M. (2008). Effect of some chemical preservatives on the shelf-life of sobo drink. African Journal of Microbiology Research, 2: 037-041.

EGBERE, O. J., ANUONYE, J. C., CHOLLOM, P. F., OKPARA, P. V. (2007) Effects of some preservation techniques on the quality and storage stability of zobo juice (a Nigerian, non- alcoholic beverage from Hibiscus sabdariffa). Journal of Food Technology, 5(3): 225-228.

EHIRI, J. E., AZUBUIKE, C. M., UBBAONU, C. N., ANYANWU, E. C., IBE, K. M., OGBONNA, M. O. (2001). Critical control points of complementary food preparation and handling in eastern Nigeria. Bulletin of the World Health Organization, 79: 423-433.

FASOYIRO, S. B., ASHAYE, O. A., ADEOLA, A., SAMUEL, F. O. (2005) Chemical and Storability of Fruit-Flavoured (Hibiscus sabdariffa) Drinks. World Journal of Agricultural Sciences 1 (2): 165-168.

FOOD AND AGRICULTURE ORGANIZATION (FAO). (2004). Hibiscus: Post-Production Management for Improved Market. INPhO- Post-harvest Compendium, p. 1-20.

FRAZIER, W. C., WESTHOFF, D. C. (1988). Food microbiology (4 th Edition) McGraw Hill Inc. New York.

IFIE, I., OLURIN, T. O., AINA, J. O. (2012). Production and quality attributes of vegetable wine from Hibiscus sabdariffa Linn. African J. of Food Science, 6(7): 212-215.

JAY, J.M., LOESSNER, M. J., GOLDEN, D. A. (2000) Modern Food Microbiology $\quad\left(7^{\text {th }}\right.$ edn). Aspen Publishers, Gaithersburg, MD http://dx.doi.org/10.1007/978-1-4615-4427-2

KOLAPO, A. L., POPOOLA, T. O. S., SANNI, M. O., AFOLABI, R. O. (2007) Preservation of soybean daddawa condiment with dichloromethane extract of ginger. Research Journal of Microbiology. 2(3):254-259.

LANCIOTTI, R., GIANOTTI, A., PATRIGNANI, N., BELLETI, N., GUERZONI, M.E., GARDINI, F. (2004). Use of natural aroma compounds to improve shelf-life of minimally processed fruits. Trends in Food Science and Technology, 15, 201-208.

http://dx.doi.org/10.1016/j.tifs.2003.10.004

LEAHU, A., DAMIAN, C., OROIAN, M., ROPCIUC, S. 2013. Physicochemical parameters of fruit juices - evolution during storage. Lucrări StiintificiceSeria Zootehnie, 59: 213-217.

LIPIPUN, V., KUROKAWA, M., SUTTISRI, R., TAWEECHOTIPATR, P., PRAMYOTHIN, P., HATTORI, M., SHIRAKI, K. (2003). Efficacy of Tha medicinal plant extracts against herpes simplex virus type 1 infection in vitro and in vivo. Antiviral Research, 6 (3):175-80. http://dx.doi.org/10.1016/S01663542(03)00152-9

McKAY, D. L., SALTZMAN, E., CHEN, C. Y., BLUMBERG, J. B. (2008) Hibiscus sabdariffa L. tea (Tisane) lowers blood pressure in prehypertensive and mildly hypertensive adults. Circulation,118, S-1123. http://dx.doi.org/10.3945/jn.109.115097

MEILGAARD, M. C., CARR, T. B., CIVILLE, G.V. (1991). Sensory Evaluation Technique, (2nd Edn). CRC Press, Boca Raton, Florida.

NOOR, R., ISLAM, Z., MUNSHI, S.H., RAHMAN, F. (2013). Influence of temperature on Escherichia coli growth in different culture media. Journal of pure and applied microbiology, 7(2): 899-904

NWAFOR, O. E., IKENEBOMEH, M. J. (2009). Effects of different packaging materials on microbiological, physio-chemical and organoleptic quality of zobo juice storage at room temperature. African Journal of Biotechnology, 8 (12):2848-2852

NWOKOCHA, J. V., OKORONKWO, N.E., EZE, S. O., NWOKOCHA, N. J. (2012). Comparism of the preservative activity of alligator pepper and ginger extracts on zobo liquor during storage at ambient temperature. Academic Research International, 2(3): 2223-9944.
NWOSU, M. O., OKAFOR, J. I. (1995). Preliminary studies on the antifungal activities of some medicinal plants against Basidiobolus and some othe pathogenic fungi. Mycoses, 38:191 - 195. http://dx.doi.org/10.1111/j.1439 0507.1995.tb00048.x

NWACHUKWU, E., ONOVO, O.M., EZEMA, C.F. (2007). Effect of lime juice on the bacterial quality of zobo juices locally produced in Nigeria. Research Journal of Microbiology, 2(10): 787-790.

$\mathrm{OBOH}$, H. A., OKHAI, E. O. (2012). Antioxidant and free radical scavenging abilities of some indigenous Nigerian drinks. Nigerian Journal of Basic and Applied Science, 20(1): 21-26.

OGBULIE, J. N., OJIEHOR, S. I., ISU, N. R., NJOKU, H. O. (1993). Effects of chemical and physical treatment on shelf-life of fermented African oil bean seed (Ugba). Nigerian Journal of Biotechnology, 22: 112-116.

OGIEHOR, I. S., NWAFOR, O. E. (2004). Associated microbial, biochemical and chemical quality changes in zobo beverage produced from Hibiscus sabdariffa. Linn. Nigerian Annals of Natural Science, 5(2): 1-10.

OGIEHOR, I. S., NWAFOR, O. E., OWHE-UREGHE, U. B. (2008). Changes in the quality of zobo beverages produced from Hibiscus sabdariffa (Lin Roselle) and the effects of extract of ginger alone or in combination with refrigeration African Journal of Biotechnology, 7(8):1176-1180.

OGIEHOR, I. S., OWHE-UREGHE, U. B., MOMODU, I. O. (1998). Microbial, chemical and organoleptic quality of palm wine preserved by combination of preservatives. Nigerian Journal of Microbiology, 12(1): 63-68.

OMEMU, A. M., EDEMA, M. O., ATAYESE, A. O., OBADINA, A. O. (2006) A survey of the microflora of Hibiscus sabdariffa (Roselle) and the resulting zobo juice. African Journal of Biotechnology, 5:254-259.

OSUNTOGUN, B. A., ABOABA, O.O. (2004). Microbiological and Physiochemical Evaluation of some Non-Alcoholic Beverages. Pakistan Journal of Nutritional, 3(3):188-192.

PADLA, E. P., SOLIS, L. T., LEVIDA, R. M., SHEN, C. C., RAGASA, C. Y. (2012). Antimicrobial Isothiocyanates from Moringa Olifera Lam. Z Naturforsch. $67 \mathrm{c} 557-564$.

PELCZAR, M. R., CHAN, E. C. S., KRIEG, N.R. (1993). Microbiology: New York: McGraw-Hill. http://dx.doi.org/10.1097/00010694-195812000-00014

SAMY, M. S. (1980). Chemical and Nutritional Studies on Roselle Seeds $\begin{array}{llllll}\text { (Hibiscus } & \text { sabdariffa } & \text { L.), } & Z & \text { Ernährungswiss. } & 19(1):\end{array}$ http://dx.doi.org/10.1007/BF02021072

SINGH, B. N., SINGH, B. R., SINGH, R. L., PRAKASH, D., DHAKAREY, R., UPADHYAY, G., SINGH, H. B. (2009). Oxidative DNA damage protective activity, antioxidant and anti-quorum sensing potentials of Moringa oleifera. Food Chemical Toxicology ${ }_{2}$ 47(6):1109-16 http://dx.doi.org/10.1016/j.fct.2009.01.034

RAY, B., BHUNIA, A. (2014). Fundamental Food Microbiology. (5 ${ }^{\text {th }}$ edn) CRC Press, Taylor and Francis Group, Boca Raton, Florida.

STONE, H., SIDEL, J. L. (2004). Sensory evaluation practices. ( ${ }^{\text {rd }}$ edn) Academic Press: San Diego, CA

TAHILIANI, P., KAR, A. (2000). Role of Moringa oleifera leaf extract in the regulation of thyroid hormone status in adult male and female rats. $\begin{array}{lll}\text { Pharmacology } & \text { Research, } & \text { 41(3):319-323 }\end{array}$ http://dx.doi.org/10.1006/phrs.1999.0587

VOIROL, E., DAGET, N. (1989). Direct nasal and oronasal profiling of a meat flavouring: influence of temperature, concentration and additives. Lebensmittel-Wissenschaft und-Technologie, 22(6): 399-405. WROLSTAD, R. E. (2000). Anthocyanins. In Natural food colorants: science and technology, New York: Marcel Dekker. 